\title{
PENGARUH SIKAP SISWA DAN MINAT BELAJAR SISWA TERHADAP HASIL BELAJAR IPA SISWA KELAS V SEKOLAH DASAR DI KABUPATEN LAMANDAU
}

\author{
Arvi Riwahyudin \\ Dosen FIP \\ arvinriwahyudin@gmail.com
}

\begin{abstract}
The purpose of this study was to determine the direct influence student attitudes and interests of student learning to the learning outcomes Elementary School fifth grade science students in District Menthobi Raya Regency Lamandau. This study uses a quantitative approach with survey method with a causal approach. Sampling study amounted to 40 respondents. Withdrawal of the number of samples using Cluster Random Sampling (Sampling Area). The findings of this research are: 1) The attitude of the students positive direct effect on learning outcomes IPA elementary school students in District Menthobi Raya Regency Lamandau. That is the positive attitude of students in the study will lead to good learning outcomes, 2) Interest in learning a direct positive effect on learning outcomes Elementary School fifth grade science students in District Menthobi Raya Regency Lamandau. This means that there is interest in learning on students will lead to good learning outcomes, 3) direct effect positive student attitude toward interest in learning science elementary school students in District Menthobi Raya Regency Lamandau.
\end{abstract}

Keywords: Student Attitude, Interest In Learning, Learning Outcomes.

\begin{abstract}
Abstrak: Tujuan penelitian ini adalah untuk mengetahui pengaruh langsung Sikap siswa dan Minat belajar siswa terhadap hasil belajar IPA siswa kelas V SD di Kecamatan Menthobi Raya Kabupaten Lamandau. Penelitian ini menggunakan pendekatan kuantitatif dengan metode survey dengan pendekatan kausal. Pengambilan sampel penelitian berjumlah 40 responden. Penarikan jumlah sampel menggunakan Cluster Random Sampling (Area Sampling). Temuan yang didapat dari penelitian ini adalah: 1) Sikap siswa berpengaruh langsung positif terhadap hasil belajar IPA siswa SD di Kecamatan Menthobi Raya Kabupaten Lamandau. Artinya sikap siswa yang positif dalam belajar akan menyebabkan hasil belajar yang baik, 2) Minat belajar berpengaruh langsung positif terhadap hasil belajar IPA siswa kelas V SD di Kecamatan Menthobi Raya Kabupaten Lamandau. Artinya minat belajar yang ada pada diri siswa akan menyebabkan hasil belajar yang baik, 3) Sikap siswa berpengaruh langsung positif terhadap minat belajar IPA siswa SD di Kecamatan Menthobi Raya Kabupaten Lamandau.
\end{abstract}

Kata kunci: Sikap siswa, Minat belajar, Hasil belajar. 
Minat memiliki peranan yang sangat penting dalam kehidupan siswa dan mempunyai dampak yang besar terhadap sikap dan prilaku. Siswa yang berminat terhadap kegiatan belajar akan berusaha lebih keras dibandingkan siswa yang kurang berminat dengan belajar. Minat sangat besar pengaruhnya terhadap hasil belajar, karena apabila bahan pelajaran yang dipelajari tidak sesuai dengan minat, siswa tidak akan belajar dengan baik sebab tidak menarik baginya.

Pembelajaran IPA di Sekolah Dasar dewasa ini belum mencapai hasil yang maksimal dan masih jauh dari apa yang diharapkan. Rendahnya mutu belajar IPA dapat diketahui dari hasil evaluasi belajar siswa. Dari segi belajar, seorang siswa akan mau dan tekun belajar atau tidak sangat tergantung pada sikap dan minat yang ada pada dirinya. Sikap dan minat sebagai faktor psikologis berbeda peranannya dalam belajar. Dalam proses belajar, sikap itu berfungsi sebagai "dynamic forces" yaitu sebagai kekuatan yang akan menggerakan orang untuk belajar. Sedangkan minat berperan sebagai "motifating forces" yaitu sebagai kekuatan yang akan mendorong siswa untuk belajar.

Menurut Asep dan Haris (2009: 14) mengatakan hasil belajar adalah pencapaian bentuk perubahan perilaku yang cenderung menetap dari ranah kognitif, afektif, dan psikomotor dari proses belajar yang dilakukan dalam waktu tertentu. Hal senada juga dijelaskan Reigeluth (1993: 98), menurutnya hasil belajar adalah perilaku yang dapat diamati yang memperlihatkan hasil belajar seseorang.

Suprijono (2009: 7) dalam bukunya menjelaskan bahwa hasil belajar adalah perubahan perilaku secara keseluruhan bukan hanya salah satu aspek potensi kemanusiaan saja. Artinya, hasil pembelajaran yang dikategorikan tidak dilihat secara fragmentaris atau terpisah, melainkan komprehensif.

Sedangkan Sukmadinata (2005: 102103), menjelaskan bahwa hasil belajar merupakan realisasi atau pemekaran dari kecakapan-kecakapan potensial atau kapasitas yang dimiliki seseorang.Penguasaan hasil belajar seseorang dapat dilihat dari perilakunya, baik dalam bentuk penguasaan pengetahuan, keterampilan berpikir maupun keterampilan motorik. Selanjutnya Sudjana (2010:3) mendefinisikan bahwa hasil belajar adalah perubahan tingkah laku siswa yang terjadi melalui proses belajar.

Lebih jauh Gagne dalam Suprijono (2009: 5-6) menjelaskan bahwa hasil belajar dapat berupa: (a) informasi verbal yaitu kapabilitas mengungkapkan pengetahuan dalam bentuk bahasa, baik lisan maupun tertulis. Kemampuan merespon secara spesifik terhadap rangsangan spesifik.Kemampuan tersebut tidak memerlukan manipulasi simbol, 
pemecahan masalah maupun penerapan aturan;

(b) keterampilan intelektual yaitu kemampuan mempresentasikan konsep dan lambang.

Keterampilan intelektual terdiri dari kemampuan mengkategorisasi, kemampuan analisis-sintetis fakta-konsep dan mengembangkan prinsip-prinsip keilmuwan; (c) strategi kognitif yaitu kecakapan menyalurkan dan mengarahkan aktivitas kognitifnya sendiri.Kemampuan ini meliputi penggunaan konsep dan kaidah dalam memecahkan masalah; (d) keterampilan motorik yaitu kemampuan melakukan serangkaian gerak jasmani dalam urusan dan koordinasi, sehingga terwujud otomatisme gerak jasmani; (e) sikap adalah kemampuan menerima atau menolak obyek berdasarkan penilaian terhadap obyek tersebut.Sikap berupa kemampuan menginternalisasi dan eksternalisasi nilai-nilai.

Winkel (2005: 56-67) juga memberikan definisi tentang hasil belajar dimana hasil belajar merupakan akibat belajar yang terjadi pada individu yang meliputi kemampuan kognitif, sensorik-motorik, dan dinamikafektif. Guru perlu mengenal hasil belajar dan kemajuan belajar siswa yang telah diperoleh sebelumnya, misalnya dari sekolah lain, sebelum memasuki sekolahnya sekarang. Halhal yang perlu diketahui itu antara lain penguasaan pelajaran, keterampilanketerampilan belajar dan bekerja. Degeng dalam Wena (2009:6-7) mengungkapkan hasil pembelajaran adalah semua efek yang dapat dijadikan sebagai indikator tentang nilai dari penggunaan strategi pembelajaran di bawah kondisi yang berbeda. Variabel hasil pembelajaran dapat diklasifikasikan menjadi tiga, yaitu: a) keefektifan pembelajaran diukur dari tingkatan pencapaian siswa, dan terdapat empat indikator untuk mendeskripsikannya, yaitu: (1) kecermatan penguasaan perilaku yang dipelajari, (2) kecepatan unjuk kerja, (3) tingkat alih belajar, dan (4) tingkat retensi; b) efisiensi pembelajaran, diukur dengan perbandingan antara keefektifan dan jumlah waktu yang dipakai siswa dan/atau jumlah biaya yang digunakan dalam pembelajaran; c) daya tarik pembelajaran, diukur dengan mengamati kecenderungan siswa untuk tetap atau terus belajar.

Lebih lanjut Hamalik

(2009:183) mengatakan bahwa perbedaan hasil belajar dikalangan para siswa disebabkan oleh berbagai faktor, antara lain: faktor kematangan akibat dari kemajuan umur kronologis, latar belakang pribadi masing-masing, sikap dan bakat terhadap suatu bidang pelajaran yang diberikan.

Usman (2009:34) Hasil belajar yang dicapai oleh siswa sangat erat kaitannya dengan rumusan tujuan pembelajaran yang direncanakan guru sebelumnya. Hal ini dipengaruhi pula oleh kemampuan guru 
sebagai perancang (designer) belajarmengajar.Untuk itu guru dituntut menguasai taksonomi hasil belajar yang selama ini dijadikan pedoman dalam perumusan tujuan pembelajaran yang tidak asing lagi bagi setiap guru.

Dalam taksonomi Bloom (1981: 7), ia mengelompokkan hasil belajar menjadi tiga ranah yakni kognitif, afektif, dan psikomotorik. dengan jabaran bahwa: 1) ranah kognitif merupakan subtaksonomi yang mengungkapkan tentang kegiatan mental yang sering berawal dari tingkat pengetahuan sampai ke tingkat yang paling tinggi yakni evaluasi, dimana ranah kognitif meliputi aspek-aspek pengetahuan, pemahaman, penerapan, analisis, sintesis dan evaluasi; 2) ranah afektif merupakan tujuan yang berhubungan dengan perasaan, emosi, sistem nilai dan sikap hati (attitude) yang menunjukkan penerimaan atau penolakan terhadap sesuatu, dimana aspek-aspeknya yakni penerimaan, tanggapan, menilai, pengorganisasian, karakterisasi; 3) ranah psikomotor adalah kawasan yang beroreintasi pada keterampilan motorik yang berhubungan dengan anggota tubuh, atau tindakan (action) yang memerlukan koordinasi antara syaraf dan otot, aspek-aspeknya meliputi gerakan seluruh badan, gerakan yang terkoordinasi, komunikasi nonverbal, dan kebolehan dalam berbicara. Anderson dan Krathwohl (2001: 8) menyatakan bahwa ranah kognitif dari Taxonomy Bloom dilakukan revisi, dimana ranah kognitif ini dibagi menjadi dua dimensi yakni dimensi kognitif proses dan dimensi pengetahuan. 1) dimensi kognitif proses dibagi menjadi enam bagian yakni mengingat, memahami, aplikasi, analisis, menilai dan mencipta; 2) dimensi pengetahuan dibagi menjadi empat bagian yakni pengetahuan faktual, pengetahuan konseptual, pengetahuan prosedural dan pengetahuan metakognisi.

Dari uraian di atas dapat disimpulkan bahwa hasil belajar adalah kemampuan yang dimiliki oleh siswa berdasarkan tujuan yang telah ditetapkan yang diperoleh ketika terjadi suatu proses pembelajaran. Hasil dari belajar IPA yang dapat di tunjukkan dari hasil perubahan dan tidak bisa menjadi bisa, atau peningkatan pengetahuan, pemahaman dan sikap.

Sikap adalah Kondisi kesiapan mental emosional untuk melakukan suatu tindakan tertentu bila suatu situasi dihadapi.Sikap menunjukkan kepada kondisi seseorang agar siap melakukan sesuatu, bukan suatu prilaku yang nyata.Setiap orang memiliki sikap yang berbeda-beda terhadap suatu perangsang. Hal ini disebabkan oleh beberapa faktor yang ada pada diri individu masing-masing seperti adanya perbedaan dalam bakat, minat, pengalaman, pengetahuan, intensitas, perasaan, dan juga situasi lingkungan. 
Berbagai pengertian diungkapkan oleh banyak ahli untuk menjelaskan arti sikap, Azwar mengutip beberapa rumusan karakter sikap yang meliputi (1) sikap memiliki arah, baik arah positif maupun negative, (2) sikap mempunyai intensitas atau kekuatan terhadap objek, (3) keluasan sikap meliputi cakupan objek-objek sikap yang disetujui atau tidak disetujui, (4) sikap memiliki konsistensi yaitu kesesuaian antara sikap dengan responnya terhadap objek, (5) spontanitas yaitu sejauh mana kesiapan subjek menyatakan sikapnya terhadap objek dengan spontan.

Pada umumnya rumusan-rumusan mengenai sikap mempunyai persamaan unsur, yaitu adanya kesediaan untuk ber-respon terhadap situasi. Pernyataan sikap di samping kategori positif dan negatif harus pula mencerminkan dimensi sikap, yakni kognisi, afeksi dan konasi.berikut ini informasi merupakan kondisi pertama untuk suatu sikap.

Menurut Syah (2001:136) dalam buku Psikologi Pendidikan dengan Pendekatan Baru menerangkan bahwa minat adalah kecenderungan dan kegairahan yang tinggi atau keinginan yang besar terhadap sesuatu.

Sedangkan menurut Djaali (2008:121) minat adalah rasa lebih suka dan ketertarikan pada satu hal atau aktivitas, tanpa ada yang menyuruh. Minat pada dasarnya adalah penerimaan akan suatu hubungan antara diri sendiri dengan suatu di luar diri, semakin kuat atau dekat hubungan tersebut, maka semakin besarnya. Sementara itu, Shaleh dan Wahab (2004:263) mengatakan bahwa "Minat juga diartikan sebagai suatu kecenderungan untuk memberikan perhatian dan bertindak terhadap orang, aktivitas atau situasi yang menjadi objek dari minat tersebut dengan disertai perasaan senang. Dalam batasan tersebut terkandung suatu pengertian bahwa di dalam minat ada pemusatan perhatian subjek, ada usaha (untuk mendekati, mengetahui, memiliki, menguasai dan berhubungan) dari subjek yang dilakukan dengan perasaan senang, ada daya penarik dari objek.

\section{METODE}

Penelitian ini dilaksanakan pada peserta didik kelas V SD di Kecamatan Menthobi Raya Kabupaten Lamandau Provinsi Kalimantan Tengah. Adapun waktu penelitian dilaksanakan pada semester I (ganjil) tahun pelajaran 2014/2015 selama 3 (tiga) bulan, yang di mulai dari bulan Agustus sampai Oktober 2014.

Metode penelitian yang digunakan dalam penelitian ini adalah survei dengan pendekatan kausal. Hasil survei dengan pendekatan kausal tersebut akan di analisis dengan menggunakan analisis jalur (path analysis).

Populasi adalah wilayah generalisasi yang terdiri atas obyek/subyek yang 
mempunyai kualitas dan karakteristik tertentu yang ditetapkan oleh peneliti untuk dipelajari dan kemudian ditarik kesimpilannya.Dalam penelitian ini populasi penelitian adalah seluruh peserta didik kelas $\mathrm{V}$ SD di Kecamatan Menthobi Raya sebanyak 213 peserta didik. Jumlah sekolah yang ada di Kecamatan Menthobi Raya Kabupaten Lamandau sebanyak 13 Sekolah Dasar.

Sampel dalam penelitian diambil dengan menggunakan teknik Cluster Random Sampling (Area Sampling) karena populasinya terdiri dari beberapa sekolah yang homogen. Dari jumlah SD di 8 (delapan) Kecamatan Setelah dilakukan pengacakan maka terpilihlah SD di wilayah kecamatan Menthobi Raya yaitu SDN Bukit Raya dan MIS Raudatul Ulum sebagai sampel dalam penelitian ini dengan jumlah sebanyak 40 siswa .

Teknik pengumpulan data dalam penelitian ini adalah melalui angket meliputi dua jenis instrumen, yaitu : (1) instrumen untuk mengumpulkan data hasil belajar IPA melalui tes dan ; (2) instrumen untuk mengumpulkan data Sikap dan Minat melalui non tes berupa angket. Sumber data dalam penelitian tindakan ini diperoleh dari Sekolah Dasar Negeri Bukit Raya dan MIS Raudatul Ulum yang berada di wilayah Kecamatan Menthobi Raya Kabupaten Lamandau kelas V sebagai objek penelitian yang berjumlah 40 orang siswa.

\section{HASIL}

Penelitian ini meliputi 3 (tiga) variabel, yaitu: sikap $\left(\mathrm{X}_{1}\right), \operatorname{minat}\left(\mathrm{X}_{2}\right)$ dan hasil belajarIPA $\left(\mathrm{X}_{3}\right)$ yang bertujuan untuk mengetahui bagaimana variabel-variabel sikap dan minat mempengaruhi secara langsung dan positif terhadap variabel hasil belajar IPA dan untuk mengetahui bagaimana variabel sikap mempengaruhi secara langsung dan positif terhadap variabel minat.

\section{A. Pengujian Persyaratan Analisis}

Untuk dapat menggunakan analisis jalur (path analysis) dalam pengujian hipotesis, terlebih dahulu perlu dilakukan prosedur pengujian prasyarat statistika terhadap data.Jika seluruh persyaratan terpenuhi, maka dapat dilanjutkan dengan analisis jalur (path analysis).Pengujian persyaratan analisis melalui 2(dua) tahap, yaitu: 1) Uji Normalitas, dan 2) Uji Regresi Linier. Pengujian persyaratan analisis, secara rinci dijelaskan sebagai berikut:

\section{Uji Normalitas Galat Taksiran}

Pengujian persyaratan normalitas masing-masing variabel dilakukan dengan maksud untuk mengetahui apakah sebaran data dari setiap variabel tidak menyimpang dari ciri-ciri data yang berdistribusi normal. Hasil dari uji normalitas dapat dilihat pada tabel 1 tentang Rangkuman hasil perhitungan uji normalitas dapat dilihat pada Tabel dibawah ini: 
Tabel 1. Rangkuman Uji Normalitas Galat Taksiran

\begin{tabular}{llllll}
\hline No & Galat Taksiran & $\mathrm{N}$ & $\mathrm{L}_{\mathrm{o}}$ & $\mathrm{L}_{\text {tabel }} \alpha=0.05$ & Keterangan \\
\hline 1 & $\mathrm{X}_{3} \operatorname{atas} \mathrm{X}_{1}$ & 40 & 0,136 & 0,140 & Normal \\
2 & $\mathrm{X}_{3}$ atas $\mathrm{X}_{2}$ & 40 & 0,091 & 0,140 & Normal \\
4 & $\mathrm{X}_{3} \operatorname{atas} \mathrm{X}_{1}$ & 40 & 0,136 & 0,140 & Normal \\
\hline
\end{tabular}

2. Uji Signifikansi dan Linearitas Model

\section{Regresi}

Persyaratan terakhir ini yang harus dipenuhi dalam melakukan analisis jalur adalah variabel-variabel bebas yang dirumuskan dalam teoritik mempunyai hubungan linear secara nyata. Oleh larena itu, dilakukan uji signifikansi dan linearitas model regresi linear sesuai dengan model hubungan antar variabel yang dirumuskan dalam model hipotesis, yang selanjutnya dilakukan uji signifikansi dan linearitas model regresi linear dengan hasil sebagai berikut :

\section{a. Hasil belajar IPA $\left(X_{3}\right)$ atas sikap $\left(X_{1}\right)$}

Dari tabel hasil ANAVA di atas tampak bahwa persamaan regresi adalah $\hat{X}_{3}=-12,777+$ $0,457 X_{1}$, hasil perhitungan pada tabel anava menunjukkan $F_{\text {hitung }}=144,288>F_{\text {tabel }}=$ 7,3525 (0,01) dan 4,098 (0,05) maka koefisien regresi signifikan. Artinya sikap memberikan peningkatan hasil belajar IPA.

Selanjutnya hasil ANAVA tersebut menunjukan bahwa nilai $F_{\text {hitung }}$ Tuna Cocok sebesar $\quad=1.8608$ $<F_{\text {tabel }}=3.31(0,01)$ dan 2,29657 $(0,05)$.

Hal ini berarti bahwa model regresi $\widehat{X}_{3}=$ $-12,389+0,453 X_{1}$ adalah linear. Model regresi tersebut mengandung arti bahwa apabila sikap ditingkat satu poin, maka hasil belajar IPA cenderung meningkat sebesar 0,453 pada konstanta -12,389. Dengan demikian dapat dikatakan bahwa pengaruh sikap $\left(\mathrm{X}_{1}\right)$ terhadap hasil belajar IPA $\left(\mathrm{X}_{3}\right)$ adalah signifikan dan linear.

\section{b. Hasil belajar IPA $\left(\mathbf{X}_{3}\right)$ atas Minat $\left(\mathbf{X}_{2}\right)$}

Hasil ANAVA di tampak bahwa persamaan regresi adalah $\hat{X}_{3}=-49,811+$ $0,968 \mathrm{X}_{2}$, dan hasil perhitungan pada tabel anava menunjukkan $F_{\text {hitung }}=788,305>$ $F_{\text {tabel }}=7,353(0,01)$ dan 4,099 $(0,05)$

maka koefisien regresi signifikan. Artinya minat memberikan peningkatan hasil belajar IPA.

Selanjutnya hasil ANAVA tersebut menunjukan bahwa nilai $F_{\text {hitung }}$ Tuna Cocok sebesar $=0.04609$ 
$<F_{\text {tabel }}=3.976(0,01)$ dan $2.587(0,05)$. Hal ini berarti bahwa model regresi $\widehat{X}_{3}=-49,811+$ $0,968 \mathrm{X}_{2}$ adalah linear. Model regresi tersebut mengandung arti bahwa apabila minat ditingkat satu poin, maka hasil belajar IPA cenderung meningkat sebesar 0,968 pada konstanta $-49,811$.

Dengan demikian dapat dikatakan bahwa pengaruh minat $\left(\mathrm{X}_{2}\right)$ terhadap hasil belajar IPA $\left(\mathrm{X}_{3}\right)$ adalah signifikan dan linear.

\section{c. Minat $\left(\mathbf{X}_{2}\right)$ atas Sikap $\left(\mathbf{X}_{1}\right)$}

Analisis regresi minat $\left(\mathrm{X}_{2}\right)$ atas sikap $\left(\mathrm{X}_{1}\right)$ bahwa persamaan regresi adalah $\widehat{X}_{2}=39.542+0,457 \mathrm{X}_{1}$, dan hasil perhitungan pada tabel anava menunjukkan $F_{\text {hitung }}=$ $135.932>F_{\text {tabel }}=$ 7,353 (0,01)dan 4,098 (0,05) maka koefisien regresi signifikan. Selanjutnya hasil ANAVA tersebut menunjukan bahwa nilai $F_{\text {hitung }}$ Tuna Cocok adalah sebesar $=2.159$ $<F_{\text {tabel }}=3.311(0,01)$ dan $2.296(0,05)$.

Hal ini berarti bahwa model regresi $\hat{X}_{2}=32,219+0,461 X_{1}$ adalah linear. Model regresi tersebut mengandung arti bahwa apabila sikap ditingkat satu poin, maka cenderung meningkat sebesar 0,461pada konstanta 32,219.

Dengan demikian dapat dikatakan bahwa pengaruh sikap $\left(\mathrm{X}_{1}\right)$ terhadap minat $\left(\mathrm{X}_{2}\right)$ adalah signifikan dan linear.

Dari pengujian prasyarat analisis, terlihat bahwa hubungan variabel bebas dengan variabel terikat adalah linear, galat baku taksiran variabel terikat terhadap variabel bebas berdisbusi normal. Dengan terpenuhi prasyarat analisis, maka pengujian selanjutnya adalah pengujian model kausalitas yang dihipotesiskan. Pengujian ini dilakukan untuk menguji apakah model yang dihipotesiskan telah menjadi model final dalam penelitian ini.

Sebelum melakukan pengujian model, maka salah satu syarat yang harus dipenuhi adalah adanya korelasi yang signifikan antara variabel yang berkait. Dari analisis regresi sederhana untuk pengujian linearitas, telah dihasilkan koefisien korelasi variabel bebas dengan variabel terikat. Koefisien korelasi tersebut kemudian disusun dalam bentuk matrik dapat kita ketahui koefisien korelasi antara sikap $\left(\mathrm{X}_{1}\right)$, minat $\left(\mathrm{X}_{2}\right)$, dan terhadap hasil belajar IPA $\left(\mathrm{X}_{3}\right)$ menyentuh pada angka 0,8. Menurut Kerlinger jika koefisien korelasi satu varibel mencapai angka 0,8 terhadap variabel lainnya bermakna terdapat hubungan yang sangat signifikan dan positif.

Hal ini menjelaskan korelasi antara sikap $\left(\mathrm{X}_{1}\right)$, minat $\left(\mathrm{X}_{2}\right)$, dan terhadap hasil belajar IPA $\left(\mathrm{X}_{3}\right)$ yang menyentuh pada angka 0,8 sangat kuat/signifikan dan positif. Dapat diasumsikan pula bahwa sikap, minat, dan merupakan indikator dari hasil belajar IPAyang saling berkaitan satu sama lain. 


\section{Pengujian Hipotesis}

\section{Uji Hipotesis Pertama}

Hasil perhitungan koefisien jalur untuk model kausal yang dihipotesiskan diperoleh nilai koefisien jalur $\beta_{13}=0,882$ dengan $t_{\text {hitung }}=$ 11,510 dan $\mathrm{t}_{\text {tabel }}=2,023$ pada $\alpha=0,05$. Karena nilai $t_{\text {hitung }}>t_{\text {tabel }}$, maka $\mathrm{H}_{0}$ ditolak. Artinya, hipotesis pertama teruji, bahwa variabel sikap berpengaruh langsung positif terhadap variabel hasil belajar IPA.

\section{Uji Hipotesis Kedua}

Hasil perhitungan koefisien jalur untuk model kausal yang dihipotesiskan diperoleh nilai koefisien jalur $\beta_{23}=0,977$ dengan $t_{\text {hitung }}=$ 28,0775 dan $\mathrm{t}_{\text {tabel }}=2,023$ pada $\alpha=0,05$. Karena nilai $t_{\text {hitung }}>t_{\text {tabel }}$ maka $H_{0}$ ditolak. Artinya, hipotesis kedua teruji, bahwa variabel minat berpengaruh positif terhadap variabel hasil belajar IPA.

\section{Uji Hipotesis Ketiga}

Hasil perhitungan koefisien jalur untuk model kausal yang dihipotesiskan diperoleh nilai koefisien jalur $\beta_{12}=0,891$ dengan $t_{\text {hitung }}$ $=12,083$ dan $t_{\text {tabel }}=2,023$ pada $\alpha=0,05$. Karena nilai $t_{\text {hitung }}>\quad t_{\text {tabel}}$, maka $H_{0}$ ditolak.Artinya, hipotesis ketiga teruji, bahwa variabel sikap berpengaruh langsung secara positif terhadap variabel minat.

\section{PEMBAHASAN}

\section{Sikap berpengaruh positif terhadap hasil belajar IPA.}

Hasil pengujian hipotesis mendukung adanya pengaruh positif sikap terhadap hasil belajar IPA.Artinya tinggi atau rendahnya sikap siswa berpengaruh positif terhadap tinggi atau rendahnya hasil belajar IPA.Semakin tinggi sikap siswa, semakin tinggi hasil belajar IPA.Sebaliknya semakin rendah sikap siswa semakin rendah hasil belajar IPA. Dari hasil perhitungan diperoleh koefisien jalur $\beta_{13}=0,882$ yang menunjukkan adanya korelasi yang sangat signifikan. Besar pengaruh sikap $\left(\mathrm{X}_{1}\right)$ terhadap hasil belajar IPA $\left(\mathrm{X}_{3}\right)$ sebesar 0,777. Artinya variasi hasil belajar IPA dapat dijelaskan oleh variasi sikap sebesar $77,7 \%$. Temuan ini mengandung implikasi bahwa hasil belajar IPA dapat ditingkatkan secara langsung melalui sikap siswa.Koefisien jalur pengaruh sikap terhadap hasil belajar IPA mengandung arti bahwa dengan membiarkan tetap pengaruh variabel lainnya, setiap peningkatan satu satuan skor sikap siswa berpengaruh terhadap peningkatan skor hasil belajar IPAsebesar 0,882 simpangan baku di atas rata-rata.

Hasil analisis tersebut dapat dipahami karena hasil belajar IPA, dipengaruhi oleh berbagai hal, baik oleh faktor yang berasal dari dalam diri individu siswa, maupun faktor yang berasal dari luar diri individu siswa. Faktor 
yang berasal dari dalam diri siswa tersebut di antaranya adalah dorongan untuk berprestasi, tanggung jawab terhadap tugas, penghargaan atas tugas, dan peluang untuk mengembangkan karakter siswa. Faktor yang berasal dari luar individu adalah situasi lingkungan pembellajaran, dan hubungan interpersonal antara siswa dan guru, dan dengan sesama siswa.

Sikap seorang siswa termasuk salah satu faktor internal yang berpengaruh terhadap hasil belajar IPA.Siswa yang sikapnya positif cenderung hasil belajarnya pun lebih tinggi dibandingkanhasil belajar IPA siswa yang sikapnya negatif. Sikap seorang siswa menentukan keberhasilan materi yang diserap dalam proses pembelajaran.Keberhasilan siswa menyerap secara baik materi ajar yang disampaikan guru dalam proses pembelajaran akan menimbulkan hasil belajar IPA positif pada individu siswa tersebut, sebaliknya ketidakberhasilan akan menyebabkan rendahnya hasil belajar IPA yang bersangkutan.

Berdasarkan tabel hasil ANAVA juga tampak bahwa sikap cukup berarti dalam mempengaruhi hasil belajar IPA, hasil perhitungan pada tabel anava menunjukkan $F_{\text {hitung }}=144,288>F_{\text {tabel }}=$ 7,3525 (0,01)dan 4,098 (0,05) maka koefisien regresi signifikan.Artinya sikap memberikan peningkatan hasil belajar IPA.
Dan selanjutnya hasil ANAVA tersebut menunjukan bahwa nilai $F_{\text {hitung }}$ Tuna Cocok sebesar

$1.8608<F_{\text {tabel }}=3.31(0,01)$ dan $2,29(0,05)$.

Hal ini berarti bahwa model regresi $\hat{X}_{3}=$ $-12,389+0,453 X_{1}$ adalah linear. Model regresi tersebut mengandung arti bahwa apabila sikap ditingkat satu poin, maka hasil belajar IPA cenderung meningkat sebesar 0,453 pada konstanta $-12,389$.

\section{Minat berpengaruh positif terhadap hasil belajar IPA. \\ Dari hasil perhitungan diperoleh} koefisien jalur $\beta_{23}=0,977$. Besar pengaruh minat $\left(\mathrm{X}_{2}\right)$ terhadap hasil belajar IPA $\left(\mathrm{X}_{3}\right)$ sebesar 0,954. Artinya variasi hasil belajar IPA dapat dijelaskan oleh variasi minat sebesar 95,4\%. Temuan ini mengandung implikasi bahwa hasil belajar IPA dapat ditingkatkan secara langsung melalui minat siswa.Koefisien jalur pengaruh minat terhadap hasil belajar IPA adalah $\beta_{23}=0,977$ mengandung arti bahwa dengan membiarkan tetap pengaruh variabel lainnya, setiap peningkatan satu satuan skor minat siswa berpengaruh terhadap peningkatan skor hasil belajar IPAsebesar 0,977 simpangan baku di atas rata-rata.

Berdasarkan tabel hasil ANAVA tampak bahwa minat cukup berarti mempengaruhi hasil belajar IPA dan berdasarkan hasil perhitungan $\quad F_{\text {hitung }}=788,305>F_{\text {tabel }}=$ 7,353 (0,01)dan 4,099 (0,05) maka 
koefisien regresi signifikan.Artinya minat memberikan peningkatan hasil belajar IPA.Selanjutnya hasil ANAVA tersebut menunjukan bahwa nilai $F_{\text {hitung }}$ Tuna Cocok $\begin{array}{lll}\text { sebesar } & = & 0.04609\end{array}$ $<F_{\text {tabel }}=3.976(0,01)$ dan $2.587(0,05)$. Hal ini berarti bahwa model regresi $\widehat{X}_{3}=-49,811+$ $0,968 \mathrm{X}_{2}$ adalah linear. Model regresi tersebut mengandung arti bahwa apabila minat ditingkat satu poin, maka hasil belajar IPA cenderung meningkat sebesar 0,968 pada konstanta $(-49,811)$.

Berdasarkan hasil perhitungan pada analisis data penelitian ini maka dapat dinyatakan bahwa terdapat pengaruh positif minat terhadap hasil belajar IPA. Dengan demikian minat mempengaruhi respon siswa terhadap materi pelajaran.Sehingga siswa yang memiliki minat yang tinggi tidak merasa kesulitan menghadapi soal-soal ujian yang diberikan kepadanya.Maka, menurut hasil penelitian minat berdampak positif terhadap hasil belajar yang diperoleh khususnya hasil belajar IPA.

\section{Sikap berpengaruh positif terhadap minat siswa.}

Hasil pengujian hipotesis mendukung adanya pengaruh positif sikap terhadap minat. Artinya tinggi atau rendahnya sikap berpengaruh positif terhadap tinggi atau rendahnya minat.Semakin tinggi sikap siswa, semakin tinggi pula minat siswa.Sebaliknya semakin rendah sikap siswa semakin rendah pula minat siswa.

Dari hasil perhitungan diperoleh koefisien jalur $\beta_{12}=0,891$. Besar pengaruh sikap terhadap minat sebesar 0,793. Artinya variasi sikap dapat dijelaskan oleh variasi minat sebesar 79,3\%. Temuan ini mengandung implikasi bahwa minat dapat ditingkatkan secara langsung melalui sikap siswa. Koefisien jalur pengaruh sikap terhadap minat adalah $\beta_{12}=0,891$. Temuan ini mengandung arti bahwa dengan membiarkan tetap pengaruh variabel lainnya, setiap peningkatan satu satuan skor sikap berpengaruh terhadap peningkatan skor minat sebesar 0,891 simpangan baku di atas rata-rata.

Berdasarkan tabel hasil ANAVA tampak bahwa sikap cukup berarti mempengaruhi minat, dan hasil perhitungan pada tabel anava menunjukkanbahwa $\quad F_{\text {hitung }}=135.932>$ $F_{\text {tabel }}=7,353(0,01)$ dan 4,098 $(0,05)$ maka koefisien regresi signifikan.Selanjutnya hasil ANAVA tersebut menunjukan bahwa nilai $F_{\text {hitung }}$ Tuna Cocok adalah sebesar $=2.159$ $<F_{\text {tabel }}=3.311(0,01)$ dan $2.296(0,05)$. Hal ini berarti bahwa model regresii $\hat{X}_{2}=32,219+0,461 X_{1}$ adalah linear. Model regresi tersebut mengandung arti bahwa apabila sikap ditingkat satu poin, maka 
cenderung meningkat sebesar 0,461pada konstanta 32,219.

Sikap menunjukkan besarnya keyakinan seseorang terhadap dirinya bahwa dia mampu menyelesaikan segala sesuatu dengan kemampuan dirinya. Dari hal tersebut dapat diketahui bahwa sikap, sebagai faktor internal dalam diri siswa yang berpengaruh terhadap minat yang menunjukkan besarnya keingintahuan siswa terhadap apa yang mereka pelajari.

\section{SIMPULAN}

Berdasarkan hasil pengujian hipotesis dan pembahasan hasil penelitian yang telah dikemukakan dalam bab sebelumnya, melalui penelitian yang dilakukan pada siswa SD di wilayah Kecamatan Menthobi Raya Kabupaten Lamandau diperoleh kesimpulan sebagai berikut :

1. Sikap siswa berpengaruh langsung positif terhadap hasil belajar IPA siswa SD di Kecamatan Menthobi Raya Kabupaten Lamandau. Artinya Sikap siswa yang positif dalam belajar akan menyebabkan hasil belajar yang baik.

2. Minat belajar berpengaruh langsung positif terhadap hasil belajar IPA siswa SD di Kecamatan Menthobi Raya Kabupaten Lamandau. Artinya minat belajar yang ada pada diri siswa akan menyebabkan hasil belajar yang baik.
3. Sikap siswa berpengaruh langsung positif terhadap minat belajar IPA siswa SD di Kecamatan Menthobi Raya Kabupaten Lamandau. Artinya sikap siswa yang baik akan meningkatkan minat belajar.

\section{DAFTAR RUJUKAN}

Anderson, Lorin W. and David R. Krathwohl. 2001. A Taxonomi for Learning, Teaching, and Assessing, A Revision of Bloom's Taxonomy of Educational Objectives.New York: Addison Wesley Longman, Inc.

Djaali. 2008.Psikologi Pendidikan. Jakarta: PT. Bumi Askara.

Hamalik, Oemar, 2009. Proses Belajar Mengajar.Jakarta: PT. Bumi Aksara.,

Jihad, Asep dan Abdul Haris. Evaluasi Pembelajaran. Yogyakarta: Multi Pressindo.

Reigeluth, Charles M. (ed), 2007.Instructional Theories In Action. New Jersey: Lawrence Erlbaum Associates, Publisher.

Sukmadinata, Nana Syaodih. 2005. Landasan Psikologi Proses

Pendidikan.Yogyakarta: PT. Remaja Rosdakarya.

Suprijono, Agus. 2009. Cooperative Learning, Teori dan Aplikasi PAIKEM. Yogyakarta: Pustaka Pelajar. 
Pengaruh Sikap Siswa dan Minat Belajar Arvi Riwahyudin

Syah, Muhubbin. 2007. Psikologi Pendidikan dengan Pendekatan Baru.Bandung: PT. Remaja Rosdakarya.

Shaleh, Abdul Rahman.dan Wahab,Muhbib Abdul. 2004. Psikologi.Jakarta: Prenada Media.

Usman, Moh. 2009. Uzer.Menjadi Guru Profesional.Bandung: PT. Remaja Rosdakarya.
Winkel, W.S. 2009. Psikologi Pengajaran. Yogyakarta: Media Abadi.,

Wena, Made. 2009. Strategi Pembelajaran Inovatif Kontenporer. Jakarta: Bumi Aksara.

Kratwohl David R. et all. 1973.Taxonomy of Educational Objectives Book 2 Affective Domain. London: Longman Group Ltd. 